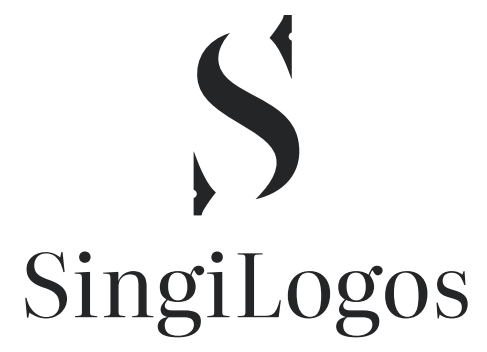

SINGILOGOS 2021, 1(1): 195 - 208

ISSN: 2812-7005

UDK: 821.111.09-31 Смит 3.

DOI: 10.18485/us_singilogos.2021.1.1.15

Original paper/Originalni naučni rad

\title{
POST-POSTMODERN BRITISH NOVEL: FUNDAMENTALISM IN ZADIE SMITH'S WHITE TEETH
}

\author{
Borjanka Đerić-Dragičević* \\ Faculty of Philology, \\ Sinergija University, \\ Bijeljina, Bosnia and Hercegovina
}

\begin{abstract}
:
The nature so as the social role of literature has undoubtedly been changing drastically since the beginning of the $21^{\text {st }}$ century. Contemporary writers want to offer different answers, and, in post-postmodern manner, to fight against or to cope with the contemporary reality, at the same time trying to re-establish human connections, and rediscover relationship with themselves as well as with the world around them. Zadie Smith is one of the novel, post-postmodern i.e. different literary voices in the contemporary British literature, who is directly depicting and deploring the new British identity, the "Britons" of the $21^{\text {st }}$ century, as well as the multicultural, cosmopolitan London. Her novel White Teeth (2000) investigates her ever present and never more influential ideas about race and deconstruction of racial stereotypes, individuality, religion, multiculturalism, identity and belonging. This paper analyses the theme of fundamentalism in this novel, trying to come to conclusion if all the characters as well as the readers have something fundamentalist in their personality. Whether these fundamentalist traits are influences by their personality, social environment, or some other circumstances. Thus, if all of us are fundamentalists in a way, what is the nature of our future? As Zadie Smith says, "We will see."
\end{abstract}

\section{Article info:}

Received: April 26, 2021

Correction: June 23, 2021

Accepted: August 2, 2021

\section{Keywords:}

post-postmodernism, hysteric realism, fundamentalism, White Teeth.

\section{INTRODUCTION}

Zadie Smith is a worldwide recognized writer whose novels are translated into more than twenty languages and who has won a number of awards for her work. She was born in London in 1975 to a Jamaican mother and an English father. Being a child and growing up in a multicultural family has influenced her later life and work. That together with the fact of living in London, which is also a cosmopolitan city, helped her form her 
ideas about race, individuality, religion, multiculturalism, identity and belonging, which are all present in her work. Race and deconstruction of racial stereotypes is something that she talked about not just in her novels but in real life as well. Being black also meant that she is not just a writer but a black writer, too. Black writers should be allowed to be just writers without emphasizing the race because "novelists have a duty to be free" 1 and they should "tell the truth through whichever veil comes to hand - but tell it"2.

Her first novel, White Teeth, was published in 2000. It became an instant bestseller and it was greeted more than well by critics. Becoming a very successful person in the world of literature at the age of only twenty-five helped her establish her position and maintain it in that same world amongst other world famous writers. Thanks to her style and the themes that she covers in her novels, there were even some comparisons with Rushdie and Amis. Besides writing, she also taught fiction at Columbia University School of Arts and she joined New York University in 2010.

\section{HYSTERIC REALISM AND FUNDAMENTALISM}

Hysteric realism and fundamentalism are the two important elements present the novel White Teeth - these elements can be recognized from the beginning till the very end of it. Hysteric realism and fundamentalism are the elements which made this novel a novel worth reading and a novel open to different interpretations which deserves its place in postmodern literary world. Smith shows, in a very dynamic way, the lives of normal people and their everyday struggles and that is something which makes it close to readers and makes it possible for them if not to identify with the characters at least to recognize them in our everyday life and surrounding.

Hysteric realism is the term made by the critic James Wood who introduced it in 2008 (How Fiction Works) to describe Zadie Smith's novel White Teeth. According to him, this and other similar novels are those who know everything about the life but have no idea about human beings. The stories in these novels are based on human beings but they are inhumane. This does not mean that these stories are impossible to happen but what is more impossible are the people in them. In other words, these novels are about the people who would not be able to live with the stories happening to them. The stories develop, but not the characters. The characters only change their minds and sometimes they are presented in a satirical way.

Hysteric realism does not abolish the elements of realism but instead these elements are overworked. Woods (2008) points out that the creators of this genre are Don DeLillo and Thomas Pynchon with their novels. Woods also claims that these novels ignore characters on the behalf of the story and that is their biggest fault. He criticizes the morality by arguing that the writers should stop telling about the world and the way it functions, instead they should start telling about the individuals and their feelings.

1 Smith Zadie (21 Jan 2018): "I have a very messy and chaotic mind". Guardian. https://www.theguardian. com/books/2018/jan/21/zadie-smith-you-ask-the-questions-self-doubt (15 May 2021)

2 Smith Zadie (21 Jan 2018): "I have a very messy and chaotic mind". Guardian. https://www.theguardian. com/books/2018/jan/21/zadie-smith-you-ask-the-questions-self-doubt(15 May 2021) 
White Teeth and other novels of this type represent disillusion of great novels that are trying to be as vital as possible at all cost and that is especially visible when it comes to characters.

Elements that Smith uses in her novel which exactly make it a part of hysteric realism novels are writer's use of satire, or sometimes she narrates through her characters and sometimes she exaggerates with the invention. She herself once called it "overblown manic prose"3. She talks about different stories and situations but she lacks the determination to unfold the real personality of her characters and that is especially present in the second part of the novel.

She depicts an Islamic terrorist group with the funny acronym KEVIN, situated in north London, and a group fighting for animal rights FATE. She portrays a Jewish scientist who is into genetic engineering, a woman born during Kingston earthquake and a group of Jehovah's witnesses. Most importantly, she describes two families that are in the center of all happenings in the novel, Samad and Archie's family. All the stories are introduced and intertwined in the most unexpected way - the very hysteric realism in action. She exaggerates in some things like when describing KEVIN leader, at other times uses satire skillfully like when describing the Chalfens.

The stories are the ones that develop and not the characters, they only change their minds. And that is the case with her characters too, Millat, from the rapper turns into a fundamentalist and Joshua from a loyal son turns into an animal-right freak. Religion is also present as a highly influential theme but at the same time almost none of the characters are truly interested in religion, they only take what is good for them and we can never say that we know their true feelings about it - also an element of hysteric realism, leaving feelings behind.

On the other hand, the term fundamentalism has different interpretations but the same common ideas. It usually has a religious connotation and is characterized by a strict literalism. When it comes to religion and religious fundamentalism it is usually described as the belief in old and traditional forms of religion or the belief that what is written in the holy book is absolutely true. Lately there are other types of fundamentalism mentioned like political, economic and cultural fundamentalism. It is hard to say whether anything good can come out of it because fundamentalism by its nature is exclusive and literal and it usually has a pejorative characterization. But when talking about non-religious fundamentalism, Roderick Hindery (2008) points out some positive characteristics such as vitality, enthusiasm, willingness to back up words with actions and avoidance of compromise. Of course, there are also negative ones such as psychological attitudes, elitist and pessimistic perspectives and literalism.

One of the characteristics of fundamentalism is that it reduces complicated reality on just few elements. It is not easy to fight fundamentalism but it is not impossible, there are many ways to do it and literature is just one of them. Literature has a specific answer to fundamentalism. The essence is not in the message that literary texts have but in the process of reading. If we want to fight fundamentalism through literature we have to read texts from different perspectives and that is the key.

3 Smith Zadie (13 Oct 2001): "This is how it feels to me". Guardian. https://www.theguardian.com/ books/2001/oct/13/fiction.afghanistan (21 May 2021) 
So, we can come to conclusion that this fundamentalist literature shares many beliefs and premises with the literature of postmodernism. The inseparable part of this paper is also questioning of postmodern premises such as the final doubt considering the (re) presentation of a story, truth and past, which influence the choices made while forming the narration in novels - we include postmodern theories of Linda Hutcheon (1988).

In Zadie Smith's White Teeth, fundamentalism is one of the central themes of the novel. Using it, the writer tries to answer the process of globalization but she ends up laughing at her characters and their fundamentalism. It is almost right to say that there are as many types of fundamentalism as there are characters in the novel (e.g. Marcus Chalfen's scientism, Millat's militant Islam or Hortense Bowen's Christianity are just some of them).

As mentioned before, the critics in hysteric realism is on morality, e.g. when we talk about Smith's fundamentalism we can notice the theme of morality but in a way that her characters and the society in general are morally confused. She talks about the fundamentalism present inside of family values, the fundamentalism of religious devotion, the fundamentalism of individuals and their necessity to emphasize the importance of being a citizen of the nation and the Earth.

She points out different manifestations of fundamentalism, different types and different reasons why people join groups and become fundamentalists. Some of them are true and some are false. Some of the fundamentalist groups mentioned in the novel are religious groups such as KEVIN (Islamic terrorist group and Jehovah's witnesses) or Fate (a group fighting for animal rights). Even though they are different in things they stand for they still have a lot in common and they share strict fundamentalist doctrine. Talking about reasons why people join certain groups, we can say that most members of KEVIN and FATE are there only to fulfil their hidden motives and not really to fight for the ideas. Just like Millat, who by joining the group gets the chance to fulfil his longtime dream to become a gangster, Joshua joins the group to be able to stand against his father. Unlike them, Hortense and Ryan truly believe in everything that Jehovah's witnesses proclaim and they live modest and humble lives according to the group rules. There is no difference between their lives and the doctrine, they are true fundamentalists. Other characters, even if not members of any fundamentalist groups, are fundamentalists in their behavior and their beliefs.

All these groups mentioned in the novel are limited in understanding and their only goal is to make others see things from their perspective and point of view. Their fundamentalism is the thing that separates them from others (Millat from Magid, Joshua from Marcus and Ryan from any possibility to have a normal relationship with a woman). In the world where we are separated by many factors, fundamentalism is just one more thing that separates us from our families and friends and from the world we live in and that is what Smith ridicules in her novel.

As Đerić (2013) points out, the struggle between prejudices and tolerance, memory and forgetting, justice and injustice is what marks the lives of the alternative voices functioning inside any traditional, mainstream, multicultural culture. One of the basic questions present in this paper is whether multicultural society fails due to too strong fundamentalist streams. 


\section{SAMAD AND HIS FUNDAMENTALISM}

As one of the main characters in the novel, Samad plays an important role for the story and its development. Calm on the surface, he is actually one of the tensest characters in the novel. Torn between his wishes and abilities, he causes lots of damage not only to himself but also to his family. His fundamentalism is shown in his desire to do everything according to tradition and religion. Unable to do it himself he tries to force it upon his family and leads it to destruction. Accepting new way of life and assimilating in the new society does not necessarily mean giving up the roots, tradition and religion. They are very important for Samad and they make the essence of his life.

"To Samad, as to the people of Thailand, tradition was culture, and culture led to roots, and these were good, these were untainted principles. That didn't mean he could live by them, abide by them or grow in the manner they demanded, but roots were roots and roots were good. You would get nowhere telling him that weeds too have tubers, or that the first sign of loose teeth is something rotten, something degenerate, deep within the gums. Roots were what saved, the ropes one throws out to rescue drowning men, to Save Their Souls. And the further Samad himself floated out to sea, pulled down to the depths by a siren named Poppy Burt Jones the more determined he became to create for his boys roots on shore, deep roots that no storm or gale could displace. Easier said than done."

Not being able to create harmony between these two sides is what makes him miserable and what makes him insist on his fundamentalist views. In a way fundamentalism for him is an escape from modern life.

From the very beginning Samad was a man who relied on his famous roots and ancestors. He was proud to be one of the Iqbals and hoped to be one of those who will make the name even more famous. But even at this point there is a contradiction. A proud member of a proud Bengali nation, he was forced to live under the government of another country. Later he fought for Britain in exchange for independence. All the things that make him strong are at the same time the things that make him weak, too. The constant fight between the old and the new is what arouses fundamentalist behavior in him. Not wanting to accept anything new or not being able to do it, he identifies it with evil while seeing tradition as the only good thing.

Sometimes he is aware of the fact that some old traditions have to be modified in order to continue their presence in the new world but that makes him even angrier and makes him hide in his fundamentalism. For example when he talks about India and its proud people he ends up attacking it because of all the things India does.

"Never go to India, Sapper Jones, my dear friend, it is a place for fools and worse than fools. Fools, Hindus, Sikhs and Punjabis. And now there is all this murmuring about independence give Bengal independence, Archie, is what I say leave India in bed with the British, if that's what she likes." 5

4 Smith 2000, 198

5 Smith 2000, 88 
Living in Britain has changed him whether he wanted to admit it or not. Unconsciously he adopted some modern ideas and styles of life, for example, when having an affair with his sons' teacher, when masturbating or drinking he behaves like almost all other British men. Doing all these, he thinks that in a way he disappointed his ancestors and maybe that he is not worth of being an Iqbal. These things are exactly the things that he tries to eliminate by turning to religion and pressuring it upon his sons and family. At times his fundamentalist religious attitudes are funny because he himself cannot live by the religious rules that he is imposing on his family. It goes that far that he even makes some arrangements with God by doing what he likes and having an excuse for it. Sometimes it seems that he is trying to wash his sins by making his family the most religious one. And that only because he is worried about his future.

"Think: I want another woman. Think: I've killed my son. I swear. I eat bacon. I regularly slap the salami. I drink Guinness. My best friend is a kaflfir non-believer. I tell myself if I rub up and down without using hands it does not count. But oh it does count. It all counts on the great counting board of He who counts. What will happen come Mahshar? How will I absolve myself when the Last Judgement comes?"6

At other times his religion seems like the true one and he behaves like a real believer, like when during the big storm he wants to take the holly book with him and pray.

According to him the root of all evil is in England and modern society. "I have been corrupted by England, I see that now my children, my wife, they too have been corrupted. I think maybe I have made the wrong friends. Maybe I have been frivolous. Maybe I have thought intellect more important than faith. And now it seems this final temptation has been put in front of me. To punish me, you understand."7

British people are the people with no moral and he is afraid of becoming one of them and even more that his sons could become real Britons. "These people who would exchange all faith for sex and all sex for power, who would exchange fear of God for self-pride, knowledge for irony, a covered, respectful head for a long, strident shock of orange hair..."

Everything would be much easier if he just admitted the fact that nothing is as it was before, that his sons are British and that they should not be punished because of that. They know little about their tradition and their roots and they can live without knowing anything more and that is something that Samad has to accept. Not wanting to let them live their lives like all other kids do, he ruins his family. Separating the two boys and sending one of them back to India thinking that it is the only way to save at least one of his sons, but in fact it is just the way to get some points with God, is the worst thing he could do. The real question is to save him from what? From the things he finds bad, from the things he does, from all the things that are minor to the boys and their lives.

Even this plan backfires. After thinking which son to send, he chooses Magid, the more intelligent one, the one that he has big hopes for. But nothing happens as he planned. Magid came back more open to new and modern British society than he ever was. He turned out to be a disappointment for Samad as much as Millat was.

6 Smith, 2000, 151

7 Smith, 2000, 145

8 Smith, 2000, 212 
In the end we can point out many things about Samad. We can say that he was a traditional man having difficult time in the modern world. We can say that he was a man closely related to his roots and wanting the same for his children but not being able to understand that times are different today and that young people can live perfectly well without knowing who their grandparents were. Or we can say that he was just a simple man who restrained himself with the tradition and who did not let himself enjoy his life. A man who did not want to allow himself any mistakes even though they are something all people make. A man who let his ancestors down, by not becoming a war hero and even by missing the end of the war. A man selfish enough to punish his family for all the bad things he did by becoming a religious fundamentalist or a man who simply wanted more for his family but did not know any other way than strict religious behaviour. A man whose roots were the most important in the world and that made him different from others. Not wanting to blend in and become one of thousands, he thought that his roots can help him with that and that was what he wanted for his children, too. He wanted them to be special, to be different and the only way they could be that was to embrace their roots. He wanted it so much that in a way he became a fundamentalist, not so much in the religious sense as much as in wanting to go back to tradition and that is what he needed tradition for. Either way Samad is the central character whose strict religious attitudes had a big influence on people around him and whose fundamentalism was something that held him in life.

\section{THE CHALFENS}

A family living in London suburb, having a little beautiful house, is exactly what the Chalfens were. Preoccupied with their work and with themselves, they had no friends but they gave their best to look like a big happy family. A scientist father, house-wife mother and children of different ages was something that made them just one of many British families. At first sight, they looked harmonious and to children like Millat and Me they were a dream family. That big is the effect they had on others.

"But Me wasn't embarrassed; she was fascinated, enamoured after five minutes. No one in the Jones household made jokes about Darwin, or said 'my foot and mouth are on intimate terms', or offered choices of tea, or let speech flow freely from adult to child, child to adult, as if the channel of communication between these two tribes was untrammelled, unblocked by history, free.." 9

Besides that they acted like a true English family and to people who did not know them they represented everything one family should represent. They seemed more English than England itself.

"It wasn't that she intended to mate with the Chalfens, but the instinct was the same. She had a nebulous fifteen-year-old's passion for them, overwhelming, yet with no real direction or object. She just wanted to, well, kind of, merge with them. She wanted their Englishness. Their Chalfishness. The purity of it. It didn't occur to her that the Chalfens were, after a fashion,

9 Smith 2000, 325 
immigrants too (third generation, by way of Germany and Poland, nee Chalfenovsky), or that they might be as needy of her as she was of them. To Me, the Chalfens were more English than the English. When Me stepped over the threshold of the Chalfen house, she felt an illicit thrill, like a Jew munching a sausage or a Hindu grabbing a Big Mac. She was crossing borders, sneaking into England; it felt like some terribly mutinous act, wearing somebody else's uniform or somebody else's skin."10

But all that was just a disguise and like every other family, what they actually were, they had their problems and faults. But they tried to be different, they tried to stand out and they tried to be something other than what they are and that is where their fundamentalism is hidden. The one who tried the most was probably the mother, Joyce.

Living with the successful husband, looking after her family and doing some pity jobs (like radio shows and books about gardening which we can call pity only when comparing it to her husband's work) was something that made her feel insecure and led to lack of self-esteem. She had a great need to do something for somebody, a need to show everyone that she is good and that she can make a difference. That was something she wanted at all cost and something that made her a fundamentalist, too. She was ready to sacrifice her own family if necessary just to get that. And eventually that is what she did.

Pretending to be a caring mother and a caring person she left her children behind in order to help some other children (Millat and Ire). But everything she did was exactly the opposite. She did not really help anyone, she only wanted to make herself feel better. She was interested in Millat's feelings but not because she really wanted to help him but because helping others was fashionable and because that is something a worthy person would do. And that was the only way Joyce could fulfil her dream and her fundamental wish to be important. So everything she did was for herself not for others and her behavior can be summarized in one sentence.

"When an Englishman wants to be generous, the first thing you ask is why, because there is always a reason." 11

Just like Samad, Joyce would be happier if she just managed to satisfy herself with the small things (if looking after your own family and being there for them is a small thing). Instead, she wanted something greater, she wanted recognition from others and in the process destroyed her family.

Unlike Joyce, her husband Marcus is a real scientist, a person who does something important and a person who will leave something for the next generations and even more for the whole nation. It is a question whether he is a fundamentalist or not. By being a scientist he does what is good for people, he fights prejudice, he breaks the limits and he doubts and questions everyone and everything. He doubts God, God does not exist for him and from Samad's point of view Marcus is a fundamentalist, the worst of all, he plays God.

Considering everything, Marcus is a fundamentalist in other people's eyes more than he actually is. It is true that he experiments on animals and maybe tomorrow he will experiment on people but that is what science does. If science is fundamentalism then Marcus is fundamentalist, too.

10 Smith 2000, 335

11 Smith 2000, 366 


\section{YOUNG GENERATIONS AND THEIR FUNDAMENTALISM}

As representatives of the young generation Millat, Magid, Irie and Joshua have even bigger problems than their parents and grandparents had when they were their age. It would be easy to say that life for young people in modern times is easier than it was in the past but at the same time it would not be true. If not more difficult and more complicated, life for young generations today is at least as hard as it was for their ancestors. Sure, their grandparents fought and died in war, they had to work hard and similar things but they knew what was expected from them and they did it. In other words, they did not have a choice and they were taught what to say and what to think. And that is the way that Samad tries to bring up his children.

Today's generations have everything but at the same time miss everything. They miss making choices for themselves and possibility to think freely and to choose freely. They are in contradiction with themselves, with their tradition and their society. They want to do one thing, their parents want them to do another thing and their society makes them do something completely different.

This is especially the case with Magid and Millat. Their father Samad thinks that by making them do something they do not like is the only way they can save themselves and the only way to do that is to return to their roots and save their identity.

Magid and Millat are twins but as they were growing up they became different and developed different interests. As little children all they wanted was to go to school and have fun with their friends. They were not concerned about their tradition, roots, religion and all the things their parents worried about. They wanted to fit in and they had no problems with that. Grownups were the ones that complicated their lives and pointed out that they were different. Instead of building bridges, grownups use every opportunity to point out the differences between people.

"Poppy Burt-Jones leant forward in her chair. "I don't know ... To me, it's just like this incredible act of self-control. We just don't have that in the West that sense of sacrifice I just have so much admiration for the sense your people have of abstinence, of self-restraint."12

That was exactly what Magid and Millat did not want. They did not want to be different from the rest of the world and to have different tradition, they wanted to live in a typical British family and do the things that a typical British family does.

"Magid really wanted to be in some other family. He wanted to own cats and not cockroaches, he wanted his mother to make the music of the cello, not the sound of the sewing machine; he wanted to have a trellis of flowers growing up one side of the house instead of the ever growing pile of other people's rubbish; he wanted a piano in the hallway in place of the broken door off cousin Kurshed's car; he wanted to go on biking holidays to France, not day-trips to Blackpool to visit aunties; he wanted the floor of his room to be shiny wood, not the orange and green swirled carpet left over from the restaurant; he wanted his father to be a doctor, not a one-handed waiter; and this month Magid had converted all these desires into a wish to join in with the Harvest Festival like Mark Smith would. Like everybody else would. "13 
As if it was not hard enough to be a teenager but they had to deal with the pressure at home. They did not have anything against their tradition and their roots but they just wanted to be left alone and in order to achieve that they did completely different things. Samad always wanted his sons to be loyal to their tradition and religion but Millat went a step further. He joined an Islamic terrorist group called KEVIN not because he was a real religious fundamentalist or anything like that but because he wanted to be free. And that made him a fundamentalist, not belonging to such a group, but wanting to be free, just he did not know any other way to do it. It was a fulfilment of his childhood dream to be a gangster, to do whatever he wants but all disguised in religious fundamentalism. Just like Millat, most of the KEVIN members were there because they had some ulterior motives, too and most of them were not real fundamentalists. They were fundamentalist in wanting to avoid living according to their tradition and rules and they did everything to be bad boys.

"Still, there was much discussion at home, at school, in the various kitchens of the widespread Iqbal/Begum clan about The Trouble with Millat, mutinous Millat aged thirteen, who farted in mosque, chased blondes and smelt of tobacco, and not just Millat but all the children: Mujib (fourteen, criminal record for joyriding), Khandakar (sixteen, white girlfriend, wore mascara in the evenings), Dipesh (fifteen, marijuana), Kurshed (eighteen, marijuana and very baggy trousers), Khaleda (seventeen, sex before marriage with Chinese boy), Bimal (nineteen, doing a diploma in Drama); what was wrong with all the children, what had gone wrong with these first descendants of the great ocean crossing experiment? Didn't they have everything they could want? Was there not a substantial garden area, regular meals, clean clothes from Marks ' $n$ ' Sparks, A-class top-notch education?"14

At first sight we can make a mistake and say that he really was trouble but if we take a better look we can only see that he was a young confused boy who give his best to be himself but did not know any better way to do it. His life was a mess and maybe he actually needed help.

"Millat was neither one thing nor the other, this or that, Muslim or Christian, Englishman or Bengali; he lived for the in between, he lived up to his middle name, Zulfikar, the dashing of two swords:"15

Not being able to influence Millat, Samad hoped that sending Magid back to India was a good thing to do and that there, Magid will realise the true values of life. By that he meant that he will learn to act in accordance with religion and that he will learn to listen and do what he is told. But it is a process and it takes time.

"But we, we do not automatically obey. We are tricky, we are the tricky bastards, we humans. We have the evil inside us, the free will. We must learn to obey. That is what I sent the child Magid Mahfooz Murshed Mubtasim Iqbal to discover."16 
Under the influence of strict religious education Magid will learn that and he was his only hope while Millat and other boys had no real model to look at and that is why they did everything wrong.

"Too safe," Samad explained, patiently consoling one or other weeping, angry ma or baba, perplexed and elderly dadu or dida, 'they are too safe in this country, accha? They live in big plastic bubbles of our own creation, their lives all mapped out for them. Personally, you know I would spit on Saint Paul, but the wisdom is correct, the wisdom is really Allah's: put away childish things. How can our boys become men when they are never challenged like men? Hmm? No doubt about it, on reflection, sending Magid back was the best thing. I would recommend it." 17

But things did not come up as expected with Magid either. He came back home being more of an Englishman than he was when he left. After getting to know his culture better, he was more sure that he does not want to be that and that is what makes him fundamentalist.

"Too often we Indians, we Bengalis, we Pakistanis, throw up our hands and cry "Fate!" in the face of history. But many of us are uneducated, many of us do not understand the world. We must be more like the English. The English fight fate to the death. They do not listen to history unless it is telling them what they wish to hear. We say "It had to be!" It does not have to be. Nothing does." 18

Similar to Millat's story is Joshua's story. He grew up in a family where father was busy with his work and mother with helping other children. He was in their shade and decided to do something about it. His choice was FATE, a fundamentalist group fighting for animal rights and against his own father. Just like Millat who became a fundamentalist because of his father, Joshua did the same but slightly different thing. He wanted to get his father's attention and he did not choose the means to do it or we can say that he chose the best one. This was a big thing, going against your own father in public and that made him a fundamentalist. A wish to be noticed and appreciated by his father was so big that it was the fundamentalism that Joshua followed. He was not aware of the consequences of his act but he did not think about them.

All three of them, Magid, Millat and Joshua did unexpected things. Living in their families made them choose the most unsuitable ways of fighting for themselves. The first two because they wanted to set themselves free from the tradition and roots and the second one because he wanted to confirm his roots and to be acknowledged by them. They chose the hardest way to do that. They were fundamentalists by their behaviour not by fighting for the general truth and rights but by fighting for their own wishes and their own life. 


\section{CONCLUSION}

Fundamentalism represents a certain type of behavior and influences not just the individuals but also the people in their surroundings. Usually defined as something negative, it often causes tragedies, individual and social. As it is shown here in all the novels mentioned, it is never simple and it has serious consequences. The reasons that lead individuals into fundamentalism are very different. As seen from these novels they can be some hidden motives disguised in fundamentalism which are there just to fulfil the needs of individuals or they can be real and true beliefs on which the life of individuals is based.

As the society develops, types and forms of fundamentalism get bigger and vary. We can even say that in a way, we are all fundamentalists, only the form and the level is different. Whether concerning religion, family, work or any other aspect of our lives, most of us at some point behave and do as fundamentalists. That does not necessarily mean that we are all ready to take some extreme measures, but that in certain times in order to fight for our rights or to protect ourselves and the people and things we care about, we are ready to do whatever is needed and in the process we often forget about other people and their feelings.

It is sometimes easy to misinterpret it with persistence, stubbornness or devotion but at the same time we can say that all these are nothing else but a form of fundamentalism and that is why we have to be very careful when dealing with it.

\section{BIBLIOGRAPHY}

Al-Salih Dheyaa Brer Alwan (2018): Exploring Multicultural Aspects in Yadie Smith's White Teeth. International Journal of Advanced Research (IJAR): 6(4), 479-486

Đerić Borjanka (2013): “Iznevjerena multikulturalnost u kanadskoj anglofonoj književnosti: tišina Japanaca u romanu Obasan Džoj Kogave", Zbornik radova sa međunarodnog naučnog skupa "Kvalitet-put u Evropu", Bijeljina, Univerzitet Sinergija: 739-748

Đerić-Dragičević Borjanka (2018): Izazovi proučavanja književnosti u 21. vijeku: post-postmodernističko viđenje stvarnosti. Zbornik sa međunarodnog naučnog skupa Sinergija 2018. Bijeljina: Univerzitet Sinergija, 73-76

Kirby Alan (2006): "Death of Postmodernism and Beyond". Philosophy Now. https://philosophynow. org/issues/58/The_Death_of_Post modernism_And_Beyond (May 1, 2021)

Liseţchi Cristina (2015): A Contemporary Representation of Reality: the Hysterical Realist Novel. Erasmus Mundus - Crossways in European Humanities: 29

Hindery Roderick (2008): "Comparative Ethics, Ideologies and Critical Thought". Journal of Religious Ethics 36.2: 215-231

Hutcheon, Linda (1988): A Poetics of Postmodernism. New York: Routledge.

Smith Zadie (2001): White Teeth. London: Vintage.

Tanaka, Shigenori (2006): English and Multiculturalism - from the Language User's Perspective. RELC Journal: 37; 47. Los Angeles: Sage Publications.

Tew, Philip (2004): The Contemporary British Novel. London-New York: Continuum. 
Smith Zadie (2018): "I have a very messy and chaotic mind," Guardian. https://www.theguardian. com/books/2018/jan/21/zadie-smith-you-ask-the-questions-self-doubt (May 1, 2021)

Wood James (2014): 'James Woods' Classic Takedown of Faux-Dickensian "Hysterical Realism", The New Republic, 14 August 2014 http://www.newrepublic.com/article/61361/human-all-tooinhuman

Wood James (2008). How Fiction Works. New York: Farrar, Straus and Giroux. 


\title{
POSTMODERNI BRITANSKI ROMAN: FUNDAMENTALIZAM U BELIM ZUBIMA ZEJDI SMIT
}

\begin{abstract}
Rezime:
Posljednjih desetak godina postoji težnja određenog broja kako književnih kritičara tako i pisaca da postmodernizam, književni pravac koji dominira od šezdesetih godina prošlog vijeka, proglase „mrtvim“, tj. da se i naučno prizna da savremena književna dijela imaju drugačiju, promijenjenu prirodu. Dok postmodernistička književna djela bivaju obojena razočaranjem, kritikom, depresijom, naše, novo vrijeme osjetno bilježi promjenu načina razmišljanja. Sa druge strane, fundamentalizam kao fenomen posljednjih godina doživljava svojevrsnu ekspanziju i to ne samo u smislu različitih vrsta nego i u smislu njegove rasprostranjenosti. Razni oblici fundamentalizma su se pojavili od vjerskog preko nacionalnog, rasnog, političkog, ekonomskog pa sve do kulturnog i mnogih drugih oblika. Svi oni su na neki način obilježili savremeno društvo i život savremenog čovjeka, kao i savremenu, post-postmodernističku književnost.

Zejdi Smit u svom romanu Bijeli zubi opisuje ličnosti u čijem svakodnevnom ponašanju možemo prepoznati obilježja fundamentalizma. Pitanje postavljeno u ovom radu jeste da li su oni po prirodi fundamentalisti ili postaju fundamentalisti pod uticajem određenih društvenih normi, te da li upornost i istrajnost u svojim željama i ciljevima ili slijepo držanje nekih uvjerenja, stavova, običaja i tradicija može da se smatra ličnim fundamentalizmom. Roman Bijeli zubi govori o dugogodišnjem prijateljstvu prvo dva čovjeka a zatim i njihovih porodica. Daje nam sliku multikulturalnog Londona i njegovih stanovnika kao i njihovih unutrašnjih dilema koje ne samo da utiču na njihov život nego i na živote njihovih porodica. Priča o pojedincima izgubljenim u modernom svijetu koji se, ne uspjevajući da se snađu u njemu, čvrsto drže nekih starih običaja što izaziva nove sukobe u njima i oko njih. Priča o drugoj generaciji imigranata koji, još postmodernistički izgubljeniji od prve, lutaju opterećeni između poštovanja nekih tradicionalnih normi i onoga što se od njih očekuje i želje da žive svoj život onako kako to žele. Sve to na određen način i njih vodi u svojevrsni fundamentalizam ili izaziva reakciju koja je opet sama po sebi fundamentalna. Savremeni svijet u kome se javljaju različiti pokreti koji se bore za različite ciljeve, u čijoj borbi mnogi pretjeruju te dolazi do pojave i raznih fundamentalističkih pa čak i terorističkih pokreta, brišu se razlike među klasama, mijenja se uloga porodice, uloga žene u društvu. Jasno je da Britanija postaje jedna multikulturalna zemlja. Ako multikulturalnost definišemo jednostavno kao kulturnu, nacionalnu, vjersku, rasnu ili bilo koju drugu raznolikost, vidimo da Britanija može služiti kao slikovit primjer multikulturalnosti migracije stanovnika koje su od kraja Drugog svjetskog rata dolaskom ljudi iz bivših kolonija a posebno devedesetih stvaranjem Evropske unije postale veoma česte. Veliki broj ljudi dolazi i traži novi i bolji život u Britaniji. Pokušavaju da se uklope u novo društvo i tako nesvjesno uzrokuju jedan novi problem a to je pitanje njihove integracije u britansko društvo koje je do tada bilo prilično heterogeno.

Na taj način, multikulturalizam ujedno postaje i jedna od glavnih tema pisaca koji su stvarali u tom periodu i bavili se problemom britanskog identiteta jer se on u ovim uslovima neizbježno mijenja. Svi zajedno su se našli u novoj i nepoznatoj situaciji i svako na svoj način su pokušavali da odgovore na nju. Britanski identitet krajem devedesetih godina prošlog vijeka i početkom dvadeset prvog vijeka nije onakav kakav je bio pedesetih godina. Treba ga redefinisati, što Zejdi Smit u svom romanu Bijeli zubi pokušava, posmatrajući fundamentalizam sa različitih aspekata.
\end{abstract}

\section{Ključne reči:}

post-postmodernizam, histerični realizam, fundamentalizam, Beli zubi. 